University of Nebraska - Lincoln

DigitalCommons@University of Nebraska - Lincoln

Roman L. Hruska U.S. Meat Animal Research

U.S. Department of Agriculture: Agricultural Center

Research Service, Lincoln, Nebraska

2001

\title{
Use of Heart Girth to Predict Body Weight of Working Oxen in the Ethiopian Highlands
}

M. R. Goe

Swiss Federal Institute of Technology, Zurich, mgoe@inw.agrl.ethz.ch

J. R. Alldredge

Washington State University, alldredg@wsu.edu

D. Light

USDA-ARS

Follow this and additional works at: https://digitalcommons.unl.edu/hruskareports

Goe, M. R.; Alldredge, J. R.; and Light, D., "Use of Heart Girth to Predict Body Weight of Working Oxen in the Ethiopian Highlands" (2001). Roman L. Hruska U.S. Meat Animal Research Center. 235.

https://digitalcommons.unl.edu/hruskareports/235

This Article is brought to you for free and open access by the U.S. Department of Agriculture: Agricultural Research Service, Lincoln, Nebraska at DigitalCommons@University of Nebraska - Lincoln. It has been accepted for inclusion in Roman L. Hruska U.S. Meat Animal Research Center by an authorized administrator of DigitalCommons@University of Nebraska - Lincoln. 


\title{
Use of heart girth to predict body weight of working oxen in the Ethiopian highlands
}

\author{
M.R. Goe ${ }^{\mathrm{a}, *}$, J.R. Alldredge ${ }^{\mathrm{b}}$, D. Light $^{\mathrm{c}}$ \\ ${ }^{a}$ Department of Animal Sciences, Swiss Federal Institute of Technology, Tannenstrasse 1, 8092 Zurich, Switzerland \\ ${ }^{\mathrm{b}}$ Program in Statistics, Washington State University, Pullman, WA 99164-3144, USA \\ ${ }^{\mathrm{c}}$ Roman L. Hruska Meat Animal Research Center, P.O. Box 166, Clay Center, NE 68933, USA
}

Received 31 December 1999; received in revised form 31 August 2000; accepted 20 November 2000

\begin{abstract}
Few studies have been conducted in sub-Saharan Africa where multiple recordings of heart girth and body weight were made for the same cattle population. In this study, monthly measurements were taken of working oxen on 24 smallholder farms in the Ethiopian highlands for 1 year. The overall yearly mean body weight of oxen across working and nonworking periods was $281 \pm 37 \mathrm{~kg}$. No significant differences in mean monthly body weights were observed, except for December and January compared to August $(297 \pm 36$ and $296 \pm 37$, and $271 \pm 35 \mathrm{~kg}$, respectively, $P<0.05)$ and December versus April $272 \pm 35 \mathrm{~kg}(P<0.05)$. Simple linear regression equations derived from body weight and heart girth measurements were significantly different between months. Nevertheless, separate monthly equations and a single equation for the year explained variation in body weight about the same. The monthly equations predicted 83 to $95 \%$ of oxen weights to within $\pm 10 \%$ of weighbridge values, while the equation for the entire year predicted $87 \%$. The $R^{2}$ values for the monthly equations ranged from 0.63 to 0.87 and the $R^{2}$ value for the entire year was 0.75 . The single equation for the year predicted body weight of oxen as a group to within $\pm 27 \mathrm{~kg}$ of mean monthly weighbridge values, whereas for a single animal the predicted body weight was $\pm 37 \mathrm{~kg}$ of the actual weight (C.I. 95\%). The single equation can be used to monitor mean body weight of the oxen population equally well across working and nonworking periods of the year. (c) 2001 Elsevier Science B.V. All rights reserved.
\end{abstract}

Keywords: Body weight; Heart girth; Oxen; Draught; Ethiopia

\section{Introduction}

Numerous studies have been conducted in subSaharan Africa to develop methods of estimating live body weight of cattle using formulae derived from body measurements. A majority of these studies

\footnotetext{
*Corresponding author. Tel.: +41-1-632-7673; fax: + 41-1632-3261.

E-mail address: mgoe@inw.agrl.ethz.ch (M.R. Goe).
}

were carried out on government research stations or private ranches with cattle populations comprised primarily of Bos indicus or zebu type breeds of mixed ages and sexes, although some included Bos taurus or European type breeds, as well as crosses between the two types (Table 1). In all the countries where the studies were done, mainly oxen, but also intact males, and in some areas cows, play an important role as draught animals, primarily for ploughing, but also for secondary cultivation (i.e., 
Table 1

Geographical distribution of studies carried out in sub-Saharan Africa to estimate live weight of cattle using formulae derived from body measurements

\begin{tabular}{|c|c|c|c|}
\hline Country & Breed/type ${ }^{\mathrm{a}}$ & Management $^{\mathrm{b}}$ & Source \\
\hline Cameroon & Peul (Adamaoua) & RS & Dumas and Lhoste (1966) \\
\hline Congo & Alur, Bahima (Ankolé) & $\mathrm{T}$ & Maricz (1961) \\
\hline Côte-d'Ivoire & Baoulé, N'Dama, Baoulé $\times$ N'Dama & RS, T & Poivey et al. (1980) \\
\hline Ethiopia & Horro, Barca, Boran and exotic crosses $^{c}$ & RS, T & Taylor and Galal (1980) \\
\hline Ethiopa & Abyssinian Short-horned zebu & $\mathrm{T}$ & Goe et al. (this work) \\
\hline Gambia & N'Dama & $\mathrm{T}$ & Spencer and Eckert (1988) \\
\hline Kenya & East African Short-horned zebu ${ }^{\mathrm{d}}$ and crosses ${ }^{\mathrm{e}}$ & $\mathrm{R}, \mathrm{T}$ & Young (1972) \\
\hline Kenya & East African Short-horned zebu and crosses ${ }^{f}$ & $\mathrm{~T}$ & Semenye (1979) \\
\hline Kenya & East African Short-horned zebu & $\mathrm{T}$ & Sandford et al. (1983) \\
\hline Malawi & Malawi zebu, Malawi zebu $\times$ Friesian & RS & Spurling (1974) \\
\hline Malawi & Malawi zebu & RS & Mwambaghi (1977) \\
\hline Mali & Maure, Peul (White Fulani) & RS & ILCA (1978) \\
\hline Nigeria & White Fulani & RS & Gates (1948) \\
\hline Nigeria & White Fulani & RS & Ross (1958a) \\
\hline Nigeria & White Fulani, Sokoto (Gudali), N'Dama & RS & Buvanendran et al. (1980) \\
\hline Nigeria & Bunaji, Sokoto (Gudali) & RS & Buvanendran and Olorunju (1985) \\
\hline Nigeria & Boran, Muturu, N'Dama & RS & Nwosu et al. (1985) \\
\hline Rwanda & Ankolé & RS & Compere (1964) \\
\hline Senegal & Gobra (Senegal Fulani) & RS & IEMVT (1978) \\
\hline Senegal & N'Dama & RS & Fall et al. (1982) \\
\hline Sierra Leone & N'Dama & $\mathrm{T}$ & Thomas and Starkey (1983) \\
\hline South Africa & Afrikander, Angus, Hereford, Sussex & RS & Bonsma and Neser (1951) \\
\hline South Africa & Ayrshire, Guernsey, Jersey & RS & Fourie (1959) \\
\hline Sudan & N'Dama & RS & Pagot and Delainer (1959) \\
\hline Sudan & Kenana (Sudan zebu) & RS & Pollott and Ahmed $(1979,1980)$ \\
\hline Sudan & Baggara zebu & $\mathrm{T}$ & Wilson and Henrici (1979) \\
\hline Swaziland & Nguni & $\mathrm{T}$ & Ogwang and Xaba (1996) \\
\hline Tanzania & Tanganyika zebu and Hereford crosses & RS & Hutchison (1959) \\
\hline Uganda & Teso zebu (Nkedi) & RS & Manning and Williams (1950) \\
\hline Uganda & Teso zebu (Nkedi) & $\mathrm{R}, \mathrm{RS}$ & Ross (1958b) \\
\hline Uganda & Ankolé, Teso zebu (Nkedi) & RS & Thornton (1960) \\
\hline
\end{tabular}

${ }^{a}$ According to Mason and Maule (1960) and Mason (1969).

${ }^{\mathrm{b}} \mathrm{T}$, Traditional (includes village, smallholder, pastoral, etc.); R, private or government ranch; RS, research station or stock farm.

${ }^{\mathrm{c}} \mathrm{F}_{1}$ with Friesian, Simmental, and Jersey.

${ }^{\mathrm{d}}$ Masai, Taita, Boran.

${ }^{\mathrm{e}}$ Masai $\times$ Sahiwal.

${ }^{\mathrm{f}}$ Boran and Sahiwal bulls.

harrowing, planting, weeding, harvesting) and other activities (e.g., carting, logging, water-lifting) (Starkey, 1988; Starkey et al., 1991). However, there is little information available on estimating live weight of working oxen using body measurements. The use of heart (chest) girth to predict body weight of castrated males is discussed in several studies (Manning and Williams, 1950; Compere, 1964; Dumas and Lhoste, 1966; Young, 1972; Mwambaghi, 1977;
Poivey et al., 1980), but no information is given whether the animals were used for draught. Ogwang and Xaba (1996) employed a pre-calibrated commercial weighband to estimate body weight of working oxen over a 6-month period, however, no prediction equation was given. Taylor and Galal (1980) recorded heart girth and body weight of oxen, but the prediction equation was derived from only a single set of measurements. Multiple recordings of heart 
girth and body weight of off-station cattle populations are limited (Wilson and Henrici, 1979; Sandford et al., 1983). A search of the Agricole, AGRIS and $\mathrm{CAB}$ International databases covering the last 20 -year period indicates a continued void in the literature of such information. Thus, the work reported here, although based on data collected in the 1980s as part of a larger study, remains unique because it monitored changes in body weight and heart girth of oxen on smallholder farms across working and nonworking periods for 12 consecutive months. The findings presented remain valid and are applicable to oxen used in the crop-livestock production system found throughout many parts of the Ethiopian highlands today. The paper also serves as a comprehensive literature review on heart girth studies carried out in sub-Saharan Africa.

\section{Materials and methods}

\subsection{Study area}

The study was carried out on 24 smallholder farms in the Debre Birhan area (latitude $9^{\circ} 40^{\circ}$ North and longitude $39^{\circ} 32^{\circ}$ East, $2800 \mathrm{~m}$ above sea level) located $130 \mathrm{~km}$ northeast of Addis Ababa in the Shewa Plateau region of the Ethiopian highlands. A traditional mixed crop-livestock system of farming is practiced (Gryseels and Anderson, 1983). Cattle, mainly Abyssinian Short-horned zebu (Alberro and Haile Mariam, 1982a,b), are raised as a source of offspring for draught power (primarily oxen) and for milk and manure. A traditional single-tined ard (maresha) pulled by a pair of oxen with a wooden shoulder yoke is used for tillage of plots, the majority of which are stone-covered and located on slopes (Goe, 1990, 1999).

\subsection{Working and nonworking periods}

Land preparation for the minor and major cropping seasons is carried out from mid-January through March or early April, and from the beginning of May through July or early August, respectively. Ploughing of drainage furrows across plots to control water runoff or initial ploughing of long term fallow $(>5$ yr) plots is done during September and October. Ploughing usually starts between 08:00 and 09:00 and ends between 12:30 and 14:00 when a break of about an hour is taken to feed and water the oxen or allow them to graze. If work is resumed or begins in the afternoon it usually ends around 17:00 so animals can be watered before the evening feeding. Oxen are used for ploughing for an average of $5.5 \mathrm{~h}$ per day (range 3 to $7.5 \mathrm{~h}$ ) and are generally not worked for more than 2 to 3 days consecutively per week. All tillage activities total between 45 to 50 days a year. Oxen and equines are used for threshing of crops 10 to 15 days per year ( 5 to $7 \mathrm{~h}$ per day), usually from mid-December through February.

\subsection{Feed resources}

On-farm feed resources for oxen include hay, straw from crop residues (mainly barley, wheat and horse bean), grazing of crop stubble and natural pastures, and green feed from crop weedings. Oxen are usually fed three times on working days and, if time permits, allowed to graze. On nonworking days, including weekends, oxen are fed in the morning before being taken for grazing and then again in the evening. At the start of the major cropping season, beginning at the end of April or early May, hay is given on working days and straw on nonworking days. As the cropping season progresses and hay supplies began to dwindle, farmers often feed a mixture of hay and straw on working days (e.g., straw in the morning, hay at noon, and straw again in the evening). Depending on the amount of stored feed supplies remaining in mid-July, there may only be straw left for feeding on working days, and grazing on nonworking days. If straw supplies become exhausted then, regardless whether it is a working or nonworking day, oxen will be totally maintained by grazing on natural pastures and crop stubble of minor season plots. From the end of August through mid-December stored feed supplies are usually depleted and animals are only grazed. However, the quality of natural pastures improves during this period following the major rains. From January through March, oxen have access to crop residues at the threshing areas. Animals are normally watered once per day. After the evening feeding, 
animals are kraaled for the night without access to feed or water.

\subsection{Measurements}

Twenty-four pairs of oxen (each pair belonging to a different farmer) were ear-tagged and age estimated according to dentition (Kikule, 1953). Heart girth and corresponding body weight measurements of animals were recorded monthly from October 1982 through September 1983. Measurements were taken on the second or third Sunday of each month between 07:00 and 08:00 before animals were fed, watered or allowed to graze. Taking measurements at this time ensured that at least $36 \mathrm{~h}$ would have passed since the most recent working day, resulting in all oxen being on the same daily feeding-grazing schedule and receiving similar feedstuffs. Differences in body weight between animals due to gut fill were considered to be minimized for each monthly weighing, although it was recognized that due to variability in the type, quality, and quantity of feed resources during the year rumino-reticulum contents would not necessarily remain constant across months. Since oxen did not have access to water or feed during the 12 to $14 \mathrm{~h}$ prior to weighing, variation in body weight, except for real differences between animals, was reduced (Hughes and Harker, 1950; Hutchison, 1959; Yates and Larkin, 1965).

Heart girth was measured while animals were standing in a crush before weighing. A plastic tape marked in centimeters $(\mathrm{cm})$ was drawn around each animal directly behind the front legs and the base of the hump. Oxen were weighed using a mobile weighbridge (Bauman, Type 2010/B). Body weight was recorded to the nearest kilogram $(\mathrm{kg})$. Heart girth measurements and weighbridge readings were taken by the same individuals throughout the study period.

\subsection{Statistical analysis}

Descriptive statistics and regression analysis of the data were carried out using a general linear models (GLM) procedure (SAS Institute, 1989). The regression relationship between body weight and heart girth were examined for each month. Analysis of covariance methods were used to test for homo- geneity of slopes and intercepts across months. Monthly mean body weight and heart girth measurements were compared using the Tukey HSD-procedure (Kuehl, 1994).

\section{Results}

Unexpected changes in farmer schedules and sickness or replacement of animals resulted in an average of $45 \pm 2.8$ oxen being weighed and taped monthly. A total of 15 oxen were replaced by farmers during the year. The mean ages of animals present for the duration of the study and those replaced were similar $(8.0 \pm 1.9 \mathrm{yr}$ and $8.2 \pm 1.9 \mathrm{yr}$, respectively). The mean body weight of oxen over the 12 -month period was $281 \pm 37 \mathrm{~kg}$. The relationship between monthly mean weights and average number of days oxen were worked per corresponding month is depicted in Fig. 1. Animals were heaviest from November through January, averaging 295 \pm 37 $\mathrm{kg}$. There were no significant differences in mean weights across months, except for December and January compared to August $(297 \pm 36$ and $296 \pm 37$, and $271 \pm 35 \mathrm{~kg}$, respectively, $P<0.05)$ and December versus April $272 \pm 35 \mathrm{~kg}(P<0.05)$. Monthly mean heart girth measurements showed little variation, ranging from $152 \pm 7$ to $155 \pm 8 \mathrm{~cm}$.

Simple linear regression equations derived from body weight and heart girth measurements were calculated for each month and for the complete year (Table 2). Tests for homogeneity of regression slopes showed no significant differences in slopes among months $(P=0.279)$. There were significant differences in intercepts by month of sampling $(P<$ $0.001)$. The coefficients of determination $\left(R^{2}\right)$ for separate monthly regression equations ranged from 0.63 in October to 0.87 in January. The $R^{2}$ for the regression equation for the complete year was 0.75 . The single equation for the year and the separate monthly equations give similar results across working and nonworking periods. The single equation predicted $87 \%$ of the oxen weights to within $\pm 10 \%$ of the weighbridge values, whereas the separate monthly equations predicted 83 to $95 \%$. The single equation for the year predicted best in January and July, with $95 \%$ of all oxen weights estimated to within $\pm 10 \%$ of weighbridge values. The separate 


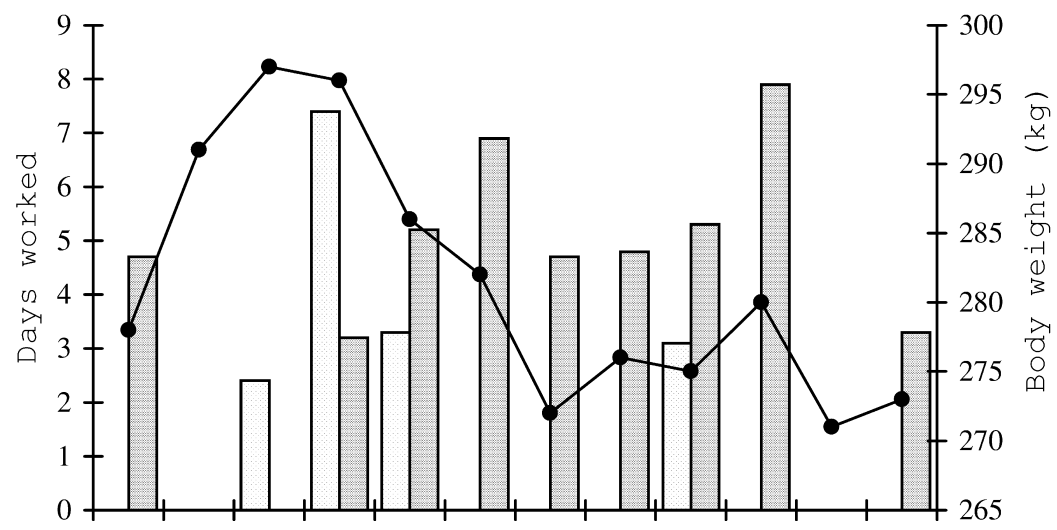

Oct $\mathrm{N}$ ov Dec Jan Feb M ar Apr M ay Jun Jul Aug Sept

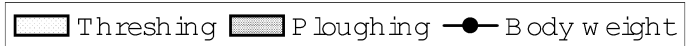

Fig. 1. Variation in monthly mean oxen weights across working and nonworking periods of the year (1982-1983) in the Debre Birhan area of the Ethiopian highlands.

Table 2

Regression equations derived from body weight and heart girth measurements of oxen on smallholder farms in the Debre Birhan area of the Ethiopian highlands

\begin{tabular}{|c|c|c|c|c|c|c|}
\hline Month & $n$ & $\begin{array}{l}\text { Mean body } \\
\text { weight (kg) }\end{array}$ & $\begin{array}{l}\text { Mean heart } \\
\text { girth }(\mathrm{cm})\end{array}$ & Equation $^{\mathrm{a}, \mathrm{b}}$ & $R^{2}$ & $\begin{array}{l}\% \text { Within } \pm 10 \% \\
\text { of weighbridge }\end{array}$ \\
\hline October & 46 & 277.8 & 153.5 & $y=3.37 x-238.6$ & 0.66 & 87 \\
\hline November & 41 & 290.6 & 154.1 & $y=3.85 x-302.1$ & 0.63 & 88 \\
\hline December & 47 & 297.5 & 154.7 & $y=3.81 x-293.1$ & 0.77 & 91 \\
\hline January & 44 & 296.1 & 155.2 & $y=4.41 x-387.8$ & 0.87 & 95 \\
\hline February & 48 & 286.4 & 153.6 & $y=4.67 x-430.7$ & 0.83 & 92 \\
\hline March & 48 & 281.7 & 152.9 & $y=4.51 x-408.0$ & 0.79 & 83 \\
\hline April & 47 & 272.5 & 152.0 & $y=4.17 x-361.9$ & 0.75 & 87 \\
\hline May & 43 & 276.1 & 153.5 & $y=4.40 x-398.6$ & 0.81 & 88 \\
\hline June & 42 & 275.0 & 153.0 & $y=4.19 x-365.8$ & 0.82 & 90 \\
\hline July & 40 & 279.6 & 154.1 & $y=4.41 x-400.1$ & 0.79 & 95 \\
\hline August & 47 & 270.7 & 152.5 & $y=4.22 x-372.1$ & 0.72 & 85 \\
\hline September & 46 & 273.1 & 154.2 & $y=4.15 x-366.6$ & 0.75 & 85 \\
\hline Overall & 539 & 281.4 & 153.6 & $y=4.21 x-364.9$ & 0.75 & 87 \\
\hline
\end{tabular}

${ }^{\mathrm{a}}$ Where $x=$ heart girth in $\mathrm{cm}$ and $y=$ predicted weight in $\mathrm{kg}$.

${ }^{\mathrm{b}}$ Significance level for all equations $P<0.001$.

equations estimated that a $1 \mathrm{~cm}$ change in heart girth would result in a weight change of 3.4 to $4.7 \mathrm{~kg}$. The overall equation estimated a $4.2 \mathrm{~kg}$ change in weight for each $1 \mathrm{~cm}$ change in heart girth. The 95\% prediction interval for the weight of an individual ox has a width of approximately $\pm 35 \mathrm{~kg}$ over the entire range of data.

\section{Discussion}

The findings indicate that body weight changes of mature working oxen in the Debre Birhan area are minimal across working and nonworking periods of the year. The extent to which the observed increases in monthly mean oxen weights, particularly from the 
end of October through January, were due to actual gain in body tissue or influenced by gut fill cannot be determined from the data collected in this study alone. Such an evaluation would require additional measurements (e.g., employing rumen-fistulated animals or the use of tritiated water to estimate fat reserves). Since little ploughing was carried out from late October to February and oxen had access to high fibre crop residues during the threshing season, it is possible that some gain in body tissue could have occurred. Improved quality of natural pastures following the major rains in July through September may also have contributed to the weight increases observed for October through January. However, because the length of time between feeding and weighing of oxen was fairly constant throughout the study, it must be suspected that rumino-reticulum contents for these 4 months might have been greater than for the rest of the year, thereby also influencing the increases in body weight observed. Studies have shown that the wet weight of rumino-reticulum contents of zebu type cattle in East Africa can equal $15 \%$ or more of body weight, depending on diet and season of the year (Hungate et al., 1959; Reed, 1983).

Heart girth measurements did not accurately reflect real differences in oxen body weights between months. Separate monthly regression equations tended to predict body weight most accurately when oxen were heaviest (i.e., December through February). As heart girth reflects animal frame size, it is possible that during this period oxen were in more uniform condition and, therefore, heart girth measurement was more accurate. However, exceptions to this can be seen for June and July when monthly mean weights were slightly below the yearly mean. Why this occurred is not clear, although possible reasons could include changes in the numbers of oxen brought for weighing each month, animals leaving and entering the group through replacement and(or) marked changes in weights of some oxen due to actual gain or gut fill. There was no bias discovered in the ability of the regression equations to predict body weight due to replacement animals.

It is known that curvilinear functions can be used in predicting animal weights over a complete growing period, provided that groups upon which the function is based are sufficiently well represented and not comprised of animals of different condition (Johansson and Hildeman, 1954). However, where there is large variation in breed, age, sex and(or) plane of nutrition across a particular population, the calculation of separate linear regression equations for groups in which these differences are minimized will usually provide the most accurate estimates of body weight (Tulloch and Maritz, 1964; Gravir, 1967; Young, 1972; Buvanendran et al., 1980; Poivey et al., 1980). In this study here, higher order polynomial equations were examined, but found not to be statistically significant. This is not surprising because the animals were mature and not growing. Similarly, $\log$ transformation of the data was unnecessary because animals had a narrow range of ages (Young, 1972; Buvanendran et al., 1980). Moreover, transformation of data requires additional mathematical calculations which further complicates the use of heart girth to provide a simple way of predicting body weight to within a known confidence interval, which is the overall purpose of the applying the technique in the field. Likewise, no attempt was made to include other body measurements [e.g., height at withers, hip height and(or) various forms of body length] in the equations. Other studies have demonstrated that such additional measurements provide little appreciable increase in accuracy of body weight estimates over equations which used heart girth alone. Even in cases where improvements were found to be significant, actual reduction in the error of live weight estimates was small (Johansson and Hildeman, 1954; Ahuja et al., 1965; Buvanendran et al., 1980; Qureshi et al., 1980; Rathi et al., 1980).

Overall, the equations developed for the complete year and for separate months predicted $85 \%$ or more of the oxen weights to within $\pm 10 \%$ of the weighbridge values. Heart girth accounted for an average of $75 \%$ of the variation in oxen body weight. These figures are comparable to results given in the studies cited in Table 1 . The ability of the regression equation for the year to explain variation in body weight nearly as well as the individual monthly equations may have implications concerning the findings of Taylor and Galal (1980) for Horro oxen in Ethiopia. A regression equation derived from body weight and heart girth measurements taken in $\mathrm{Au}$ gust-September predicts about the same percentage 
Table 3

Comparison of regression equations derived from body weight and heart girth measurements of Abyssinian Short-horned and Horro oxen

\begin{tabular}{llllllrl}
\hline Breed & Month & $n$ & $\begin{array}{l}\text { Mean weight } \\
(\mathrm{kg})\end{array}$ & $\begin{array}{l}\text { Mean heart } \\
\text { girth }(\mathrm{cm})\end{array}$ & Equation $^{\text {a }}$ & $\begin{array}{c}R^{2} \\
\begin{array}{l}\% \text { within } \pm 10 \% \\
\text { of weighbridge }\end{array}\end{array}$ \\
\hline $\begin{array}{l}\text { Abyssinian } \\
\text { Short-horned }\end{array}$ & August & 48 & 269 & 152 & $y=4.11 x-354$ & 0.65 & 85 \\
$\begin{array}{l}\text { Abyssinian } \\
\begin{array}{l}\text { Short-horned } \\
\text { b }\end{array}\end{array}$ & September & 46 & 273 & 154 & $y=4.15 x-367$ & 0.75 & 85 \\
Horro $^{c}$ & August/September & 102 & 265 & 151 & $y=4.17 x-363$ & 0.87 & 89 \\
\hline
\end{tabular}

${ }^{\mathrm{a}}$ Where $y=$ weight $(\mathrm{kg})$ and $x=$ heart girth $(\mathrm{cm})$.

${ }^{\mathrm{b}}$ Present study.

${ }^{\mathrm{c}}$ Data from Taylor and Galal (1980).

of animal weights to within $\pm 10 \%$ of the weighbridge values as the two respective monthly equations from this study (Table 3). The similarities between the three equations and the mean values for heart girth and body weight for the two studies suggests that a characteristic heart girth to body weight relationship exists among the Sanga type zebu breeds of oxen in the Ethiopian highlands. Whether the regression equations (complete year or monthly) developed in the present study could be used to estimate weights of other types of Abyssinian zebu oxen (i.e., Jigiga or Small zebu and Jem Jem or Black zebu) which are similar in size and weight to Short-horned zebu (Alberro and Haile Mariam, 1982a,b) would require further investigation.

\section{Conclusions}

Oxen continue to provide the main source of power for tillage on smallholder farms in the Ethiopian highlands. It is recommended that the prediction equation for the complete year be used to estimate oxen weights on farms around Debre Birhan and in the surrounding areas. The equation will be most accurate when used to estimate the mean body weight of a particular population of oxen (e.g., periodic village level or market surveys or vaccination campaigns), rather than the weight of an individual animal. It is important that the purpose for which oxen weights are required is identified. If extremely accurate results are required (e.g., draught force or feed intake expressed as a percentage of body weight) then a weighbridge should be used. The most optimum and efficient system of acquiring information on body weight of oxen may involve the use of heart girth in conjunction with a weighbridge. Heart girth could be used to obtain estimates of body weight during periods of the year when animal management is consistent and feed resources relatively constant, whereas during the dry season, a weighbridge would provide the most accurate method of assessing changes in oxen weights. In situations where only general information is required regarding overall animal condition and actual body weights are not necessary (e.g., monitoring animal performance on natural pasture or rangelands), then consideration might be given to the use of body condition scoring (Nicholson and Butterworth, 1986; Nicholson and Sayers, 1987). However, as with heart girth, changes in body weight may not be accurately correlated with indicies represented by body condition scoring (Osuji and Capper, 1992).

\section{Acknowledgements}

This study was funded by the International Livestock Centre for Africa (now the International Livestock Research Institute), Addis Ababa. Support provided by Frank M. Anderson and Woldeab W/ Mariam is appreciated. Special thanks to the members of the field team, especially Mohamed Yasin and Yirsaw Wubete. Comments on earlier drafts of the manuscript by Robert E. McDowell, Jess D. Reed and John C.M. Trail were useful. 


\section{References}

Alberro, M., Haile Mariam, S., 1982a. The indigenous cattle of Ethiopia, Part 1. Wld. Anim. Rev. 41, 2-10.

Alberro, M., Haile Mariam, S., 1982b. The indigenous cattle of Ethiopia, Part 2. Wld. Anim. Rev. 42, 27-34.

Ahuja, L.D., Goswami, R.P., Kuchhawah, S.S., 1965. Estimation of body weight of zebu cows from heart girth measurement. Ann. Arid Zone 4, 17-23.

Bonsma, J.C., Neser, F.W.C., 1951. Practical application of growth studies on cattle: the relationship between chest girth and weight. Fmg. S. Afr. 26, 365-374.

Buvanendran, V., Umoh, J.E., Abubakar, B.Y., 1980. An evaluation of body size as related to weight of three West African breeds of cattle in Nigeria. J. Agric. Sci. Camb. 95, 219-224.

Buvanendran, V., Olorunju, S.A.S., 1985. Chest girth measurements in selection for body weight in cattle. J. Anim. Prod. Res. 5, 125-130.

Compère, R., 1964. Contribution a l'etude de la conformation du betail local Rwanda de type Ankole. Rev. Élev. Méd. Vét. Pays Trop. 17, 273-305.

Dumas, R., Lhoste, 1966. Variations du poids vif et du rendement en viande de boeufs zebus de l'Adamaoua au cours de la saison. Rev. Élev. Méd. Vét. Pays Trop. 19, 573-579.

Fall, A., Diop, M., Sandford, J., Wissocq, Y.J., Durkin, J., Trail, J.C.M., 1982. Evaluation of the Productivities of Djallonke Sheep and N'Dama Cattle at the Centre de Recherches Zootechniques, Kolda, Senegal. Report No. 3. ILCA, Addis Ababa.

Fourie, P.D., 1959. Weighbands for dairy cows are reliable. Fmg. S. Afr. 35, 22-23.

Gates, 1948. A Guide for Veterinary Assistants in Nigeria. Government Printer, Lagos.

Goe, M.R., 1990. Tillage with the traditional maresha in the Ethiopian highlands. Tools \& Tillage 6, 127-156.

Goe, M.R., 1999. Influence of slope and stone cover on tillage operations in the Ethiopian highlands. Soil \& Tillage Res. 49, 289-300.

Gravir, K., 1967. Studies on different body measurements as estimators of live and carcass weight in young NRF bulls. Acta Agric. Scand. 17, 217-227.

Gryseels, G., Anderson, F.M., 1983. Research On Farm and Livestock Productivity in the Central Ethiopian Highlands: Initial Results 1977-1980. Research Report No. 4. ILCA, Addis Ababa.

Hungate, R.E., Phillips, G.D., McGregor, A., Hungate, D.P., Beuchner, H.K., 1959. Microbial fermentation in certain mammals. Science 130, 1192-1194.

Hughes, G.P., Harker, K.W., 1950. The technique of weighing bullocks on summer grass. J. Agric. Sci. Camb. 40, 403-409.

Hutchison, H.G., 1959. Variations in liveweight of cattle on farm and ranch in Tanganyika. E. Afr. Agric. For. J. 24, 279-285.

IEMVT, 1978. Mis au point d'une formule barymetrique adaptee au zebu Gobra. In: Rapport d'Activite, Annee 1977. Institut d'Elevage et de Medecine Veterinaire des Pays Tropicaux, Maisons Alfort, pp. 103-104.

ILCA, 1978. Evaluation of the Productivities of Maure and Peul
Cattle Breeds at the Sahelian Station, Niono, Mali. Monograph 1. ILCA, Addis Ababa.

Johansson, I., Hildeman, S.E., 1954. The relationship between certain body measurements and live and slaughter weight in cattle. Anim. Breed. Abstr. 22, 1-17.

Kikule, S.B., 1953. Age-changes in teeth of Zebu cattle. E. Afr. Agric. For. J. 19, 86-88.

Kuehl, R.O., 1994. Statistical Principles of Research Design and Analysis. Duxbury Press, Belmont, CA.

Manning, H.L., Williams, E., 1950. A note on the estimation of liveweight of cattle in Uganda. E. Afr. Agric. For. J. 16, 94-96.

Maricz, M., 1961. Etude comparative des race de zébus et trois races de bétail de l'Est du Congo. Bull. Agric. Congo 52, $107-116$.

Mason, I.L., Maule, J.P., 1960. The Indigenous Livestock of Eastern and Southern Africa. Commonwealth Agricultural Bureau, Farnham Royal.

Mason, I.L., 1969. A World Dictionary of Livestock Breeds, Types and Varieties. Commonwealth Agricultural Bureau, Farnham Royal.

Mwambaghi, F.R.M., 1977. An Assessment of Relationship Between Body Dimensions and Bodyweight in Three Cattle Samples. (B.S. Research Report). University of Malawi, Bunda College of Agriculture, Lilongwe.

Nicholson, M.J., Butterworth, M.H., 1986. A Guide to Condition Scoring of Zebu Cattle. ILCA, Addis Ababa.

Nicholson, M.J., Sayers, A.R., 1987. Relationships between body weight, condition score and heart girth changes in Boran cattle. Trop. Anim. Health Prod. 19, 115-120.

Nwosu, C.C., Akhionbare, F.N., Iboh, I.E., 1985. Characterization of cattle in Nigeria - body measurements. Beitr. Trop. Landw. Vetmed. 23, 89-97.

Ogwang, B.H., Xaba, B., 1996. The effect of feeding agroindustrial by-products on weight gain and body condition of draft oxen in Swaziland. In: Ndikumana, J., de Leeuw, P. (Eds.), Proceedings of the 2nd African Feed Resources Network (AFRNET) Workshop, Harare, 6-10 December 1993, Sustainable Feed Production and Utilisation For Smallholder Livestock Enterprises in Sub-saharan Africa. African Feed Resources Network, Nairobi, pp. 165-167.

Osuji, P.O., Capper, B.L., 1992. Effect of age on fattening and body condition of draught oxen fed teff straw (eragrostis teff) based diets. Trop. Anim. Health Prod. 24, 103-108.

Pagot, J., Delainer, R., 1959. Etude biometrique de la croissance des taurins N'Dama. Rev. Élev. Méd. Vét. Pays Trop. 12, 405-416.

Poivey, J.P., Landais, E., Seitz, J.L., 1980. Utilisation de la barymetrie chez les races taurines locales de Cote-d'Ivoire. Rev. Élev. Méd. Vét. Pays Trop. 33, 311-317.

Pollott, G.E., Ahmed, F.A., 1979. The Relationship Between Liveweight and Heartgirth in a Herd of Kenana Heifers (Sudan Zebu). Um Banein Livestock Research, Bulletin, Sudan. No. 9.

Pollott, G.E., Ahmed, F.A., 1980. The relationship between liveweight and heartgirth in a herd of Kenana heifers (Sudan Zebu). Anim. Breed. Abstr. 48, 330.

Qureshi, M.I., Taylor, C.M., Singh, B.W., 1980. Note on correla- 
tion studies between different body measurements and body weight in Gir cows. Indian J. Anim. Sci. 50, 877-878.

Rathi, S.S., Balaine, D.S., Singh, B., Chhikara, B.S., 1980. Estimation of body weights through body measurements in different genetic groups of cattle. Indian J. Dairy Sci. 33, 410-411.

Reed, J.D., 1983. The nutritional ecology of game and cattle on a Kenyan ranch. Ph.D. Thesis. Cornell University, Ithaca, NY.

Ross, J.G., 1958a. The estimation of liveweight of White Fulani Zebu cattle in Nigeria from linear body measurements. Bull. Epiz. Dis. Afr. 6, 37-41.

Ross, J.G., 1958b. A method of estimating live-weights in small shorthorn Zebu cattle from linear body measurements. E. Afr. Agric. For. J. 23, 193-194.

Sandford, J., Durkin, J., Trail, J.C.M., 1983. Evaluation of cattle weight estimation by band at Muhaka, Kenya. Working Document. ILCA, Nairobi.

SAS Institute, 1989. 4th Edition. SAS/STAT User's Guide, Version 6, Vol. 2. SAS Institute, Cary, NC.

Semenye, P.P., 1979. The Estimation of Liveweight of Zebu Cattle From Heart Girth Measurements. Working Document. ILCA, Nairobi.

Spencer, W.P., Eckert, J.B., 1988. Estimating live weight and carcass weight in Gambian N'Dama cattle. Wld Anim. Rev. 65, $18-23$.

Spurling, D., 1974. In: Annual Report of the Department of Agriculture (Animal Husbandry Research) 1970-71, Bvumbwe
Research Station, Limbe, Malawi. Government Printer, Zomba, pp. $48-52$.

Starkey, P.H., 1988. Animal Traction Directory: Africa. Vieweg for German Appropriate Technology Exchange, GTZ, Eschborn.

Starkey, P.H., Teklu, S., Goe, M.R., 1991. Animal Traction: An Annotated Bibliographic Database. ILCA, Addis Ababa.

Taylor, M.S., Galal, E.S.E., 1980. The relationship between liveweight and heartgirth for some Ethiopian Zebu and crossbred cattle. Ethiopian J. Agric. Sci. 2, 39-49.

Thomas, L., Starkey, P.H., 1983. Working Paper. Sierra Leone Work Oxen Project. Ministry of Agriculture and Forestry, Tower Hill, Freetown.

Thornton, D.D., 1960. The estimation of Ankole and Zebu cattle weights by girth measurement. E. Afr. Agric. For. J. 26, 140-141.

Tulloch, N.M., Maritz, J.S., 1964. Comparative breed studies of beef cattle, Part 2. Changes in size and shape. Aust. J. Agric. Res. 15, 316-332.

Wilson, R.T., Henrici, A., 1979. A new method for the estimation of live weight from girth measurements in Baqqara cattle in the Sudan. Bull. Anim. Health Prod. Afr. 27, 145-150.

Yates, R.J., Larkin, P.J., 1965. Minimal error weight measurements in cattle experiments. E. Afr. Agric. For. J. 30, 263-264.

Young, D.L., 1972. The estimation of liveweight from heart girth within specified age/sex groups of Kenyan range cattle. E. Afr. Agric. For. J. 38, 193-200. 